\title{
Aeromicrobium alkaliterrae sp. nov., isolated from an alkaline soil, and emended description of the genus Aeromicrobium
}

Correspondence
Jung-Hoon Yoon
jhyoon@kribb.re.kr

The genus Aeromicrobium was first described by Miller et al. (1991) with a single species, Aeromicrobium erythreum. Subsequently, Nocardioides fastidiosa was transferred to the genus as Aeromicrobium fastidiosum (Tamura \& Yokota, 1994). One further species, Aeromicrobium marinum, was described recently (Bruns et al., 2003). Phylogenetic analyses based on 16S rRNA gene sequences showed that the genus Aeromicrobium belongs to the family Nocardioidaceae (Stackebrandt et al., 1997; Yoon et al., 1998; Bruns et al., 2003). In this study, we report on the taxonomic characterization of an Aeromicrobium-like strain, KSL-107 ${ }^{\mathrm{T}}$, which was isolated from an alkaline soil in Korea.

Alkaline soil (approx. pH 10.0) collected from Kwangchun, Korea, was used as the source for the isolation of bacterial strains. Strain KSL- $107^{\mathrm{T}}$ was isolated by the standard dilution plating technique at $25^{\circ} \mathrm{C}$ on $10 \times$ diluted nutrient agar (NA; Difco) with $\mathrm{pH}$ adjusted to $10 \cdot 0$ by using $\mathrm{Na}_{2} \mathrm{CO}_{3}$. A. erythreum DSM $8599^{\mathrm{T}}$ and A. marinum DSM $15272^{\mathrm{T}}$ were

Published online ahead of print on 10 June 2005 as DOI 10.1099/ ijs.0.63582-0.

Abbreviation: DAP, 2,6-diaminopimelic acid.

The GenBank/EMBL/DDBJ accession number for the 16S rRNA gene sequence of strain KSL-107 ${ }^{\top}$ is AY822044.

A table detailing the cellular fatty acid composition of strain KSL-107 ${ }^{\top}$ is available as supplementary material in IJSEM Online. obtained from the Deutsche Sammlung von Mikroorganismen und Zellkulturen (DSMZ). A. fastidiosum KCTC $9576^{\mathrm{T}}$ was obtained from the Korean Collection for Type Cultures (KCTC). The morphological, physiological and biochemical characteristics of strain KSL-107 ${ }^{\mathrm{T}}$ were investigated using routine cultivation on trypticase soy agar (TSA; Difco) at $25^{\circ} \mathrm{C}$. Cell morphology was examined by light microscopy (E600; Nikon) and transmission electron microscopy (TEM). The presence of flagella was examined by TEM using cells from exponentially growing cultures. The Gram-reaction was determined by using the bioMérieux Gram Stain kit according to the manufacturer's instructions. Growth at various $\mathrm{NaCl}$ concentrations was investigated in trypticase soy broth (TSB; Difco) and TSB lacking $\mathrm{NaCl}$. Growth at various temperatures $\left(4-40{ }^{\circ} \mathrm{C}\right)$ was measured on TSA. The $\mathrm{pH}$ range for growth was determined in TSB adjusted to various $\mathrm{pH}$ values $(\mathrm{pH} 4 \cdot 5-12 \cdot 0$ at intervals of $0.5 \mathrm{pH}$ units). The $\mathrm{pH}$ was adjusted prior to sterilization by the addition of $\mathrm{HCl}$ or $\mathrm{Na}_{2} \mathrm{CO}_{3}$ (below

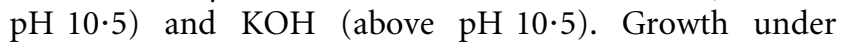
anaerobic conditions was determined after incubation in an anaerobic chamber on TSA and TSA supplemented with nitrate, both of which had been prepared anaerobically using nitrogen. Catalase and oxidase activities and hydrolysis of casein, hypoxanthine, starch, tyrosine, xanthine and Tweens 20, 40, 60 and 80 were determined as described by Cowan \& Steel (1965). Hydrolysis of aesculin, gelatin and urea and nitrate reduction were studied according to Lanyi 
(1987). Utilization of various substrates as sole carbon and energy sources was determined as described by Shirling \& Gottlieb (1966). Enzyme activity was determined by using the API ZYM system (bioMérieux). The need for vitamins for growth was investigated using the liquid medium used for substrate utilization tests supplemented with $0 \cdot 4 \%$ $(\mathrm{w} / \mathrm{v})$ glucose as the sole carbon and energy sources. Vitamins were added to the medium at the following concentrations (per litre): biotin $(2 \mathrm{mg})$, thiamin hydrochloride $(2 \mathrm{mg})$ and nicotinic acid $(2 \mathrm{mg})$. Other physiological and biochemical tests were performed with the API
20E system (bioMérieux). Morphological, cultural, physiological and biochemical properties of strain KSL- $107^{\mathrm{T}}$ are shown in Table 1 or are given in the species description (see below).

Chromosomal DNA was isolated and purified according to the method described by Yoon et al. (1996) with the exception that RNase T1 was applied in combination with RNase A. The $16 \mathrm{~S}$ rRNA gene was amplified by PCR using two universal primers as described previously (Yoon et al., 1998). Sequencing of the amplified 16S rRNA gene and

\section{Table 1. Differential phenotypic characteristics of Aeromicrobium species}

Species: 1, A. alkaliterrae sp. nov.; 2, A. erythreum (data from Miller et al., 1991); 3, A. fastidiosum (Collins \& Stackebrandt, 1989; Tamura \& Yokota, 1994); 4, A. marinum (Bruns et al., 2003). All species are aerobic, positive for Gram stain, esterase (C4), esterase lipase (C8) and leucine arylamidase. All species are negative for lipase (C14), valine arylamidase, cystine arylamidase, trypsin, $\alpha$-chymotrypsin, $\alpha$ galactosidase, $\beta$-galactosidase, $\beta$-glucuronidase, $\beta$-glucosidase, $N$-acetyl- $\beta$-glucosaminidase, $\alpha$-mannosidase and $\alpha$-fucosidase. + , Positive; - , negative; w, weakly positive; ND, not determined.

\begin{tabular}{|c|c|c|c|c|}
\hline Characteristic & 1 & 2 & 3 & 4 \\
\hline Cell morphology & Rods, cocci & Irregular rods, cocci & Rods, cocci & Rods \\
\hline Catalase & + & + & ND & + \\
\hline Urease & - & - & - & ND \\
\hline Nitrate reduction & - & - & ND & - \\
\hline Motility & - & - & + & - \\
\hline Optimal temperature for growth $\left({ }^{\circ} \mathrm{C}\right)$ & 25 & 35 & 25 & 25 \\
\hline Growth at $10^{\circ} \mathrm{C}$ & + & - & + & + \\
\hline Biotin and thiamin required for growth & - & + & + & ND \\
\hline \multicolumn{5}{|l|}{ Hydrolysis of: } \\
\hline Aesculin & - & + & ND & ND \\
\hline Casein & + & + & + & - \\
\hline Cellulose & - & + & - & - \\
\hline Gelatin & + & + & + & ND \\
\hline Starch & - & + & + & - \\
\hline \multicolumn{5}{|l|}{ Utilization of: } \\
\hline L-Arabinose & + & + & + & - \\
\hline Citrate & - & ND & + & - \\
\hline D-Fructose & - & + & + & - \\
\hline D-Glucose & + & + & ND & - \\
\hline Maltose & + & - & - & - \\
\hline D-Mannose & - & - & + & - \\
\hline Pyruvate & - & ND & + & + \\
\hline Salicin & + & - & ND & ND \\
\hline Sucrose & + & + & ND & - \\
\hline D-Trehalose & + & + & ND & + \\
\hline D-Xylose & - & + & ND & - \\
\hline \multicolumn{5}{|l|}{ API ZYM:* } \\
\hline Acid phosphatase & + & + & + & - \\
\hline Alkaline phosphatase & - & - & + & - \\
\hline$\alpha$-Glucosidase & + & + & + & - \\
\hline Naphthol-AS-BI-phosphohydrolase & + & $\mathrm{W}$ & $\mathrm{W}$ & $\mathrm{W}$ \\
\hline DNA G $+C$ content $(\mathrm{mol} \%)$ & $71 \cdot 5$ & $71-73$ & $71-72$ & $70 \cdot 6$ \\
\hline
\end{tabular}

${ }^{\star}$ Data from the type strains obtained in this study. 
phylogenetic analysis were performed according to Yoon et al. (2004). An almost-complete $16 \mathrm{~S}$ rRNA gene sequence of strain KSL- $107^{\mathrm{T}}$ was determined in this study and comprised $1473 \mathrm{nt}$, representing approximately $96 \%$ of the Escherichia coli 16S rRNA gene sequence. A neighbourjoining phylogenetic tree based on $16 \mathrm{~S}$ rRNA gene sequences revealed that strain KSL- $107^{\mathrm{T}}$ falls within the cluster with Aeromicrobium species (Fig. 1). The same tree topologies were found using the maximum-likelihood and maximumparsimony algorithms (data not shown). Similarity values between the 16S rRNA gene sequences of strain KSL-107 ${ }^{\mathrm{T}}$ and the type strains of Aeromicrobium species ranged from $97.9 \%$ (with A. erythreum and A. fastidiosum) to $98 \cdot 2 \%$ (with A. marinum). Sequence similarities to other species used in the phylogenetic analysis were lower than $93.5 \%$. DNA-DNA hybridization was performed fluorometrically by the method of Ezaki et al. (1989) using photobiotinlabelled DNA probes and microdilution wells. Hybridization was performed with five replications for each sample. The highest and lowest values obtained in each sample were excluded and the means of the remaining three values were quoted as DNA-DNA relatedness values. Mean DNA-DNA relatedness levels between strain KSL-107 ${ }^{\mathrm{T}}$ and the type strains of three Aeromicrobium species with validly published names were in the range of $11-17 \%$, indicating that strain $\mathrm{KSL}-107^{\mathrm{T}}$ represents a distinct genomic species.

Cell biomass for isoprenoid quinone and cell-wall analyses and for DNA extraction was obtained from cultures grown in TSB at $25^{\circ} \mathrm{C}$. The isomer type of the diamino acid in the cell-wall peptidoglycan was determined using TLC according to the method described by Komagata \& Suzuki (1987). Isoprenoid quinones were analysed according to Komagata \& Suzuki (1987) using reverse-phase HPLC. For fatty acid methyl ester (FAME) analysis, a loop of cell mass was harvested after cultivation for 6 days on NA and TSA at $25^{\circ} \mathrm{C}$. FAMEs were extracted and prepared according to

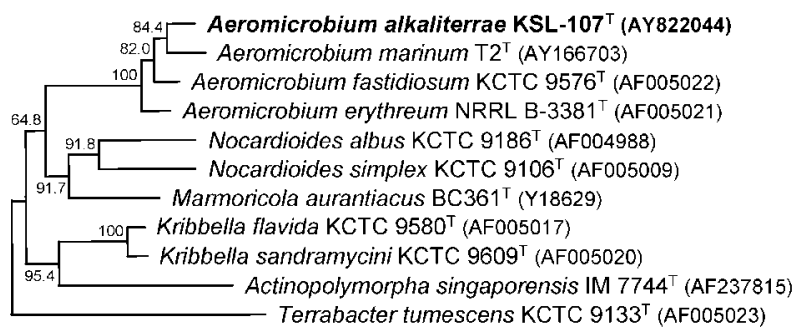

$\underline{0.01}$

Fig. 1. Neighbour-joining tree based on 16S rRNA gene sequences showing the phylogenetic positions of strain KSL$107^{\top}$ and representatives of some related taxa. Bootstrap values (1000 replications) are shown as percentages at each node. Bar, 0.01 substitutions per nucleotide position. the standard protocol of the MIDI/Hewlett Packard Microbial Identification System (Sasser, 1990). The DNA $\mathrm{G}+\mathrm{C}$ content was determined by the method of Tamaoka \& Komagata (1984) with a modification that DNA was hydrolysed and the resultant nucleotides were analysed using reverse-phase HPLC and a YMCODS-A $(250 \times 4 \cdot 6 \mathrm{~mm})$ column. Strain KSL-107 ${ }^{\mathrm{T}}$ contained LL-2,6-diaminopimelic acid (LL-DAP) as the diagnostic diamino acid in the cell-wall which is characteristic of wall chemotype I sensu Lechevalier \& Lechevalier (1970). The isolate contained a tetrahydrogenated menaquinone with nine isoprene units [MK-9 $\left.\left(\mathrm{H}_{4}\right)\right]$ as the predominant isoprenoid quinone. This menaquinone type was different from that found in the genera Nocardioides, Marmoricola and Actinopolymorpha (Park et al., 1999; Urzì et al., 2000; Wang et al., 2001). When strain KSL-107 was cultivated on TSA and NA, the fatty acid profiles were characterized by a common core of straight-chain, unsaturated, hydroxy and 10-methyl fatty acids in varying amounts (see Supplementary Table S1 in IJSEM Online). When cultivated on TSA, the fatty acids $(>1.0 \%)$ detected were $\mathrm{C}_{16: 0}(34 \cdot 1 \%), \mathrm{C}_{16: 0} 2-\mathrm{OH}(17 \cdot 6 \%), 10$-methyl $\mathrm{C}_{18: 0}$ (16.3\%), $\mathrm{C}_{18: 1} \omega 9 c(5 \cdot 7 \%), 10$-methyl $\mathrm{C}_{17: 0}(5 \cdot 0 \%), 10$ methyl $\mathrm{C}_{16: 0}(4 \cdot 0 \%), \mathrm{C}_{17: 0}(3 \cdot 5 \%), \mathrm{C}_{16: 1} \omega 7 c$ and/or iso- $\mathrm{C}_{15: 0} 2-\mathrm{OH}(3 \cdot 4 \%), \mathrm{C}_{15: 0}(3 \cdot 2 \%), \mathrm{C}_{17: 1} \omega 8 c(2 \cdot 4 \%)$, $\mathrm{C}_{18: 0}(1 \cdot 2 \%)$ and $\mathrm{C}_{14: 0}(1 \cdot 0 \%)$. No significant differences in the fatty acid profiles were found between strain KSL$107^{\mathrm{T}}$ and Aeromicrobium species (Park et al., 1999; Bruns et al., 2003). The fatty acid profiles of strain KSL- $107^{\mathrm{T}}$ were different from those of members of the genus Nocardioides, the closest phylogenetic neighbour (Park et al., 1999; Bruns et al., 2003). Branched fatty acids, particularly iso- $C_{16: 0}$, which are major components in Nocardioides species, were minor components in strain KSL-107 ${ }^{\mathrm{T}}$ and Aeromicrobium species as determined by most authors (Park et al., 1999; Urzì et al., 2000; Bruns et al., 2003; Yi \& Chun, 2004; Yoon et al., 2004). Fatty acid $\mathrm{C}_{16: 0}$, a minor component in Nocardioides species, was a major component in strain KSL- $107^{\mathrm{T}}$ and Aeromicrobium species. The tuberculostearic acid (10-methyl $\mathrm{C}_{18: 0}$ ) content of strain KSL-107 ${ }^{\mathrm{T}}$ was greater than that of Nocardioides species in most experiments (Park et al., 1999; Bruns et al., 2003; Yi \& Chun, 2004; Yoon et al., 2004). The DNA G $+\mathrm{C}$ content of strain KSL- $107^{\mathrm{T}}$ was $71 \cdot 5 \mathrm{~mol} \%$.

Comparative 16S rRNA gene sequence analyses showed that strain KSL- $107^{\mathrm{T}}$ is most closely related to the genus Aeromicrobium of the family Nocardioidaceae (Fig. 1). Chemotaxonomic properties support the monothetic phylogenetic classification of strain KSL- $107^{\mathrm{T}}$ as a member of the genus Aeromicrobium. The phenotypic differentiation and phylogenetic and genetic distinctiveness are sufficient to categorize strain KSL- $107^{\mathrm{T}}$ as a species that is distinct from the recognized Aeromicrobium species (Wayne et al., 1987; Stackebrandt \& Goebel, 1994). Therefore, on the basis of the data presented, strain KSL- $107^{\mathrm{T}}$ should be placed in the genus Aeromicrobium as a member of a novel species, for which the name Aeromicrobium alkaliterrae sp. nov. is proposed. 


\section{Description of Aeromicrobium alkaliterrae sp. nov.}

Aeromicrobium alkaliterrae (al.ka.li.ter'rae. N.L. n. alkali alkali; L. gen. n. terrae of the soil or earth; N.L. gen. n. alkaliterrae of alkaline soil).

Cells are rods $(0 \cdot 3-0.5 \times 0 \cdot 8-1.4 \mu \mathrm{m})$ or cocci. Grampositive. Non-motile. Non-endospore-forming. Colonies are circular, convex, smooth, glistening, cream-coloured and $1.0-1.5 \mathrm{~mm}$ in diameter after 7 days cultivation at $25^{\circ} \mathrm{C}$ on NA. Aerial mycelium is not formed. Growth occurs at $4{ }^{\circ} \mathrm{C}$, but not at $36^{\circ} \mathrm{C}$. Optimal initial $\mathrm{pH}$ for growth is 7.0-7.5; growth occurs at initial $\mathrm{pH} 6 \cdot 0$ and $11 \cdot 0$, but not at initial $\mathrm{pH} 5 \cdot 5$ and $11 \cdot 5$. Optimal growth occurs in the absence of $\mathrm{NaCl}$; growth does not occur in the presence of $>9 \%(\mathrm{w} / \mathrm{v}) \mathrm{NaCl}$. Biotin, thiamin and nicotinic acid are not required for growth. Growth does not occur under anaerobic conditions on TSA or on TSA supplemented with nitrate. Oxidase-negative. Tweens 20, 40, 60 and 80 are hydrolysed. Hypoxanthine, tyrosine and xanthine are not hydrolysed. $\mathrm{H}_{2} \mathrm{~S}$ and indole are not produced. Voges-Proskauer reaction is negative. Arginine dihydrolase, lysine decarboxylase, ornithine decarboxylase and tryptophan deaminase are absent. D-Galactose, Dcellobiose, succinate and L-malate are utilized. D-Ribose, acetate, benzoate and formate are not utilized. The cellwall peptidoglycan contains LL-DAP as the diagnostic diamino acid. The predominant menaquinone is $\mathrm{MK}$ $9\left(\mathrm{H}_{4}\right)$. The major fatty acids are $\mathrm{C}_{16: 0}, \mathrm{C}_{16: 0} 2-\mathrm{OH}$ and 10methyl $\mathrm{C}_{18: 0}$. The DNA $\mathrm{G}+\mathrm{C}$ content is $71.5 \mathrm{~mol} \%$ (determined by HPLC). Other phenotypic properties are given in Table 1 .

The type strain, KSL-107 ${ }^{\mathrm{T}}\left(=\mathrm{KCTC} 19073^{\mathrm{T}}=\mathrm{DSM} 16824^{\mathrm{T}}\right.$ ), was isolated from an alkaline soil in Kwangchun, Korea.

\section{Emended description of the genus Aeromicrobium Miller et al. 1991}

The emended description is based on the original description given by Miller et al. (1991), the data compiled by Collins \& Stackebrandt (1989), Tamura \& Yokota (1994) and Bruns et al. (2003) and those generated in this study. Cells are aerobic, non-endospore-forming, Gram-positive, cultures contain rods and cocci or rods. Non-motile or motile. Mesophilic; optimal temperature for growth is about $25-35{ }^{\circ} \mathrm{C}$. Heterotrophic; a wide range of carbon sources are used for growth and various organic compounds are hydrolysed. The cell-wall peptidoglycan contains LL-DAP as the diagnostic diamino acid. The predominant menaquinone is $\mathrm{MK}-9\left(\mathrm{H}_{4}\right)$. The major fatty acids are 10-methyl $\mathrm{C}_{18: 0}, \mathrm{C}_{16: 0}$ and both or either of $\mathrm{C}_{18: 1} \omega 9 c$ and $\mathrm{C}_{16: 0} 2-\mathrm{OH}$. The DNA G + C content is 70.6-73 mol\%. Members of this genus form a coherent group within the radiation of the family Nocardioidaceae on the basis of $16 \mathrm{~S}$ rRNA gene sequence data. Members of the genus occur in various habitats, including soils, herbage and sea water. The type species is Aeromicrobium erythreum.

\section{Acknowledgements}

This work was supported by the 21C Frontier program of Microbial Genomics and Applications (grant MG02-0401-001-1-0-0) from the Ministry of Science and Technology (MOST) of the Republic of Korea.

\section{References}

Bruns, A., Philipp, H., Cypionka, H. \& Brinkhoff, T. (2003). Aeromicrobium marinum sp. nov., an abundant pelagic bacterium isolated from the German Wadden Sea. Int J Syst Evol Microbiol 53, 1917-1923.

Collins, M. D. \& Stackebrandt, E. (1989). Molecular taxonomic studies on some LL-diaminopimelic acid-containing coryneforms from herbage: description of Nocardioides fastidiosa sp. nov. FEMS Microbiol Lett 57, 289-294.

Cowan, S. T. \& Steel, K. J. (1965). Manual for the Identification of Medical Bacteria. London: Cambridge University Press.

Ezaki, T., Hashimoto, Y. \& Yabuuchi, E. (1989). Fluorometric deoxyribonucleic acid-deoxyribonucleic acid hybridization in microdilution wells as an alternative to membrane filter hybridization in which radioisotopes are used to determine genetic relatedness among bacterial strains. Int J Syst Bacteriol 39, 224-229.

Komagata, K. \& Suzuki, K. (1987). Lipids and cell-wall analysis in bacterial systematics. Methods Microbiol 19, 161-207.

Lanyi, B. (1987). Classical and rapid identification methods for medically important bacteria. Methods Microbiol 19, 1-67.

Lechevalier, M. P. \& Lechevalier, H. A. (1970). A critical evaluation of the genera of aerobic actinomycetes. In The Actinomycetales, pp. 393-405. Edited by H. Prauser. Jena: Gustav Fischer Verlag.

Miller, E. S., Woese, C. R. \& Brenner, S. (1991). Description of the erythromycin-producing bacterium Arthrobacter sp. strain NRRL B-3381 as Aeromicrobium erythreum gen. nov., sp. nov. Int J Syst Bacteriol 41, 363-368.

Park, Y.-H., Yoon, J.-H., Shin, Y. K., Suzuki, K.-I., Kudo, T., Seino, A., Kim, H.-J., Lee, J.-S. \& Lee, S. T. (1999). Classification of 'Nocardioides fulvus' IFO 14399 and Nocardioides sp. ATCC 39419 in Kribbella gen. nov., as Kribbella flavida sp. nov. and Kribbella sandramycini sp. nov. Int J Syst Bacteriol 49, 743-752.

Sasser, M. (1990). Identification of Bacteria by Gas Chromatography of Cellular Fatty Acids. Newark: MIDI Inc.

Shirling, E. B. \& Gottlieb, D. (1966). Methods for characterization of Streptomyces species. Int J Syst Bacteriol 16, 313-340.

Stackebrandt, E. \& Goebel, B. M. (1994). Taxonomic note: a place for DNA-DNA reassociation and $16 \mathrm{~S}$ rRNA sequence analysis in the present species definition in bacteriology. Int J Syst Bacteriol 44, 846-849.

Stackebrandt, E., Rainey, F. A. \& Ward-Rainey, N. L. (1997). Proposal for a new hierarchic classification system, Actinobacteria classis nov. Int J Syst Bacteriol 47, 479-491.

Tamaoka, J. \& Komagata, K. (1984). Determination of DNA base composition by reverse-phase high-performance liquid chromatography. FEMS Microbiol Lett 25, 125-128.

Tamura, T. \& Yokota, A. (1994). Transfer of Nocardioides fastidiosa Collins and Stackebrandt 1989 to the genus Aeromicrobium as Aeromicrobium fastidiosum comb. nov. Int $J$ Syst Bacteriol 44, 608-611.

Urzì, C., Salamone, P., Schumann, P. \& Stackebrandt, E. (2000). Marmoricola aurantiacus gen. nov., sp. nov., a coccoid member of the family Nocardioidaceae isolated from a marble statue. Int J Syst Evol Microbiol 50, 529-536. 
Wang, Y. M., Zhang, Z. S., Xu, X. L., Ruan, J. S. \& Wang, Y. (2001). Actinopolymorpha singaporensis gen. nov., sp. nov., a novel actinomycete from the tropical rainforest of Singapore. Int J Syst Evol Microbiol 51, 467-473.

Wayne, L. G., Brenner, D. J., Colwell, R. R. \& 9 other authors (1987). International Committee on Systematic Bacteriology. Report of the ad hoc committee on reconciliation of approaches to bacterial systematics. Int J Syst Bacteriol 37, 463-464.

Yi, H. \& Chun, J. (2004). Nocardioides ganghwensis sp. nov., isolated from tidal flat sediment. Int J Syst Evol Microbiol 54, 1295-1299.
Yoon, J.-H., Kim, H., Kim, S.-B., Kim, H.-J., Kim, W. Y., Lee, S. T., Goodfellow, M. \& Park, Y.-H. (1996). Identification of Saccharomonospora strains by the use of genomic DNA fragments and rRNA gene probes. Int J Syst Bacteriol 46, 502-505.

Yoon, J.-H., Lee, S. T. \& Park, Y.-H. (1998). Inter- and intraspecific phylogenetic analysis of the genus Nocardioides and related taxa based on 16S rDNA gene sequences. Int J Syst Bacteriol 48, 187-194.

Yoon, J.-H., Kim, I.-G., Kang, K. H., Oh, T.-K. \& Park, Y.-H. (2004). Nocardioides aquiterrae sp. nov., isolated from groundwater in Korea. Int J Syst Evol Microbiol 54, 71-75. 